\title{
Evaluation of traditional Brazilian sausage (linguiça calabresa) elaborated with oregano and basil extracts as natural antioxidants
}

\section{Avaliação da linguiça calabresa elaborada com extratos de orégano e manjericão como antioxidantes naturais}

\author{
Daniele Cristina Savoldi ${ }^{1 *}$; Fernanda Jéssica Mendonça ${ }^{1}$; Bárbara Geremia \\ Vicenzi ${ }^{1}$; Denis Fabrício Marchi²; João Francisco Marchi3i; Ivane Benedetti Tonial4; \\ Adriana Lourenço Soares ${ }^{5}$
}

\section{Highlights}

Freeze-dried basil and oregano extracts were prepared.

Basil and oregano extracts were assessed for antioxidant activity.

Antioxidant extracts were used in linguiça calabresa preparation.

\section{Abstract}

This study aimed to evaluate traditional Brazilian sausage (linguiça calabresa) elaborated with oregano and basil extracts as natural antioxidants. Hydroalcoholic extracts of dried oregano and basil leaves were prepared, freeze-dried, and evaluated for antioxidant activity by Folin-Ciocalteu, DPPH, FRAP, and ABTS assays. Freeze-dried oregano extract showed higher $(p<0.05)$ antioxidant activity than freeze-dried basil extract by all methods. Extracts were used in preparations of seven sausage formulations, as follows: $\mathrm{F} 1,0.05 \%$ oregano extract and $0.05 \%$ basil extract; $F 2,0.1 \%$ oregano extract and $0.05 \%$ basil extract; F3, $0.05 \%$ oregano extract and $0.1 \%$ basil extract; $F 4,0.075 \%$ oregano extract and $0.075 \%$ basil extract, F5, $0.1 \%$ oregano extract and $0.1 \%$ basil extract; F6 (control), without extract; and F7, $0.01 \%$ butylated hydroxytoluene (BHT). Sausage formulations were analyzed for chemical composition, $\mathrm{pH}$, acidity, water activity, lipid oxidation, color, and texture. Formulations showed differences in $\mathrm{pH}$ at different storage periods. F1, F2, F3, and F7 had the lowest ( $p<0.05$ ) lipid oxidation values at 53 days of storage. F1, F2, F6, and F7 showed higher $a^{*}$ values and lower $b^{*}$ values. Hardness and chewiness decreased $(p<0.05)$ during

1 Doctoral Students of the Postgraduate Program in Food Sciences, Universidade Estadual de Londrina, UEL, Londrina, PR, Brazil. E-mail: danycs_pr@hotmail.com; fernanda.mendonca@live.com; barbarageremiavicenzi@gmail.com

2 Prof. Dr., Instituto Federal do Paraná, IFPR, Londrina, PR, Brazil. E-mail: denis.marchi@ifpr.edu.br

3 Prof. M.e, Academic Department of Food Engineering, Universidade Tecnológica Federal do Paraná, UTFPR, Francisco Beltrão, PR, Brazil. E-mail: joaomarchi@utfpr.edu.br

4 Profa Dra, Postgraduate Program in Food Technology, Academic Department of Chemistry and Biological Sciences, UTFPR, Francisco Beltrão, PR, Brazil. E-mail: ivane@utfpr.edu.br

5 Profa Dra, Postgraduate Program in Food Science, Department of Food Science and Technology, UEL, Londrina, PR, Brazil. E-mail: adri.soares@uel.br

* Author for correspondence

Received: Apr. 16, 2021 - Approved: Aug. 13, 2021 
storage for all formulations. F1, F2, and F3 had similar efficiency to that with synthetic antioxidant BHT (F7), therefore, oregano and basil extracts have potential application as natural antioxidants in the food industry. Key words: Phenolic compounds. Lipid oxidation. Meat products.

\section{Resumo}

Este estudo objetivou avaliar linguiça calabresa elaborada com extratos de orégano e manjericão como antioxidantes naturais. Extratos hidroalcoólicos de orégano e manjericão desidratados foram preparados, liofilizados e submetidos a avaliação de sua atividade antioxidante pelos métodos de FolinCiocalteu, DPPH, FRAP e ABTS. O extrato liofilizado de orégano apresentou maior atividade antioxidante $(p<0,05)$ que o extrato de manjericão para todos os métodos. Os extratos liofilizados foram usados em sete formulações de linguiça calabresa, como segue: F1 com $0,05 \%$ de cada extrato, F2 com 0,1\% de extrato de orégano e $0,05 \%$ de extrato de manjericão, F3 com $0,05 \%$ de extrato de orégano e 0,1\% de extrato de manjericão, F4 com $0,075 \%$ de cada extrato, F5 com 0,1\% de cada extrato, F6 (controle), sem adição de extratos e F7 adição de 0,01\% de hidroxitolueno butilado (BHT). As linguiças calabresas foram avaliadas, quanto a composição química, $\mathrm{pH}$, acidez, atividade de água, oxidação lipídica, cor e textura. As formulações apresentaram variação de $\mathrm{pH}$ nos diferentes períodos de estocagem. As formulações F1, F2, F3 e F7 apresentaram os menores valores de oxidação lipídica $(p<0,05)$ aos 53 dias de armazenamento. As formulações F1, F2, F6 e F7 apresentaram maiores valores de $a^{*}$ e menores valores de b*. Observouse redução $(p<0,05)$ de dureza e mastigabilidade ao longo do período de armazenamento para todas as formulações. As formulações F1, F2 e F3 apresentaram eficiência similar à formulação com antioxidante sintético BHT (F7), portanto, os extratos de orégano e manjericão tem potencial como antioxidante natural na indústria de alimentos.

Palavras-chave: Compostos fenólicos. Oxidação lipídica. Produtos cárneos.

\section{Introduction}

Meats and meat products are sources of high biological value protein, lipid, vitamins, and mineral salts (Oliveira, Lage, Silveira, \& Sales, 2012; Paschoal et al., 2019). Lipids play an important role in food quality, as they contribute to important sensory properties, such as aroma, flavor, juiciness, and nutritional value (Zago et al., 2020). However, high-lipid products are highly susceptible to oxidative reactions. This is particularly true for fresh meat and derived products, given their high content of polyunsaturated fatty acids and pro-oxidizing substances, such as iron ions, as well as processing methods to which products are subjected, including comminution and cooking, which can increase oxidation rates (Brewer, 2011; Oliveira et al., 2012; Lima, Rangel, Urbano, \& Moreno, 2013; Faion et al., 2015; Leão et al., 2017).

Oxidative reactions not only reduce the nutritional value of food but also degrade fat-soluble vitamins and essential fatty acids. As a result, unpleasant and potentially toxic compounds are formed, affecting food integrity and storage life (Leygonie, Britz, \& Hoffman, 2012; Oliveira et al., 2012; Lima et al., 2013; Faion et al., 2015; Ribeiro et al., 2019). To prevent such changes, the food industry adds antioxidants, either natural or synthetic, to food products (Karre, Lopez, \& Getty, 2013; Shah, Bosco, \& Mir, 2014; Leão et al., 2017). 
Natural antioxidants have been gaining the preference of consumers, who have sought to adopt healthier diets as a means of preventing diseases, prioritizing foods from natural sources and with fewer additives (Mariutti \& Bragagnolo, 2007; Zhang, Xiao, Samaraweera, Lee, \& Ahn, 2010; Brewer, 2011; Oliveira et al., 2012; Fernandes et al., 2016a). Some synthetic antioxidants are known to harm human health (Oliveira et al., 2012; Shah et al., 2014; Taghvaei \& Jafari, 2015; Zehiroglu \& Sarikaya, 2019).

Studies have aimed to discover natural products with antioxidant activity that can partially or fully replace synthetic antioxidants (Sousa et al., 2007; Shah et al., 2014; Taghvaei \& Jafari, 2015; Ribeiro et al., 2019), such as condiments, aromatic herbs, and spices (Mariutti \& Bragagnolo, 2007; Fernandes et al., 2016a). Antioxidant properties in plants and vegetables are associated with the presence of phenolic compounds, which can stabilize lipid oxidation reactions (Marangoni \& Moura, 2011; Oliveira et al., 2012). Oregano (Origanum vulgare L.) and basil (Ocimum basilicum L.), which are members of the family Lamiaceae, are well-known for their antioxidant, antimicrobial, and medicinal properties (Mariutti \& Bragagnolo, 2007).

Oregano produces essential oils widely applied in the food industry. Some components, such as carvacrol and thymol, exhibit antioxidant and antimicrobial properties (Fukayama, Bertechini, Geraldo, Kato, \& Murgas, 2005; Bhale, Xu, Prinyawiwatkul, King, \& Godber, 2007; Del Ré \& Jorge, 2012; Pitaro, Fiorani, \& Jorge, 2012; Gandra et al., 2013; Gonçalves, Santos, \& Morais, 2015). Basil essential oil has important flavor, antimicrobial, and antioxidant properties (Mariutti \& Bragagnolo, 2007; Del Ré \& Jorge, 2012). Its antioxidant activity is comparable to that of the widely used antioxidants butylated hydroxytoluene (BHT) and $\alpha$-tocopherol (Del Ré \& Jorge, 2012). The antioxidant capacities of basil extract and essential oil are related to their high concentrations of phenolic compounds (Mendes, Rodrigues-das-Dores, \& Campideli, 2015; Gonçalves et al., 2015). Carvacrol, caffeic acid, and rosmarinic acid are the components mainly responsible for the antioxidant properties of oregano extract (Oliveira et al., 2012), whereas eugenol, thymol, and carvacrol are associated with the antioxidant activity of basil extract (Del Ré \& Jorge, 2012).

This study aimed to evaluate traditional Brazilian sausage (linguiça calabresa) elaborated with oregano and basil extracts as natural antioxidants.

\section{Material and Methods}

\section{Material}

Dried basil (Ocimum basilicum L.) and oregano (Origanum vulgare L.) leaves were purchased from a local market in the city of Londrina, Paraná State (Brazil). These dehydrated spices were evaluated for moisture by drying (Oven ASL 102, Solab, Brazil) at 105 ${ }^{\circ} \mathrm{C}$ (Association of Official Analytical Chemists [AOAC], 1995).

\section{Extract preparation}

Dried leaf extracts of basil and oregano were prepared by the procedures described by Pitaro et al. (2012), with modifications. About $10 \mathrm{~L}$ of each extract was prepared by mixing the plant material and $70 \%$ ethanol at a weight/ volume ratio of $1: 10$, grinding the mixture in a 
blender (Philco, 1200 W, Brazil), and leaving it to rest for $24 \mathrm{~h}$ at room temperature. Samples were vacuum-filtered and the solvent removed by rotary evaporation (Rotary Evaporator Marconi, MA-120, Brazil) at $50{ }^{\circ} \mathrm{C}$ and $72 \mathrm{rpm}$. The extracts were then frozen at $-18{ }^{\circ} \mathrm{C}$ and freeze-dried (Martin Christ Alpha 1-2 LD Plus, Germany) to a powder after $48 \mathrm{~h}$.

The freeze-dried extracts were resuspended in $70 \%$ ethanol to a stock concentration of $1.0 \mathrm{~g} \mathrm{~L}^{-1}$, in triplicate, for further antioxidant activity analyses. The antioxidant activity was evaluated by reducing capacity measurement, as well as DPPH radical-scavenging, FRAP, and ABTS assays, diluting extracts according to each method.

\section{Measure of reducing capacity}

Reducing capacity was determined by the Folin-Ciocalteu method, as described by Kumazawa, Hamasaka and Nakayama (2004), with modifications, using gallic acid as standard. Results were expressed in grams of gallic acid equivalent (GAE) per gram of extract.

\section{2,2-Diphenyl-1-picrylhydrazyl (DPPH) radical scavenging assay}

The method of Brand-Williams, Cuvelier and Berset (1995), as modified by Rufino et al. (2007a), was used to determine the DPPH radical-scavenging activity of extracts. Results were expressed as $\mathrm{EC}_{50}$ values, defined as the amount of sample (in grams) required to reduce the initial DPPH concentration by $50 \%$.
Ferric reducing antioxidant power (FRAP) assay

The ferric reducing antioxidant power (FRAP) method was performed according to the methodology described by Benzie and Strain (1996) and Sánchez-González, JiménezEscrig and Saura-Calixto (2005). Results were expressed in mmol Trolox equivalents $\mathrm{g}^{-1}$ extract.

\section{2,2'-Azino-bis(3-ethylbenzothiazoline-6- sulfonic acid) (ABTS) assay}

The ABTS method was performed following the procedures described by Rufino et al. (2007b). Results were determined against a standard curve of Trolox (100-2000 umol $\mathrm{mL}^{-1}$ ) and expressed in mmol Trolox equivalents $\mathrm{g}^{-1}$ extract.

\section{Preparation of linguiça calabresa (traditional Brazilian sausage)}

Table 1 shows the seven formulations of linguiça calabresa prepared, from F1 to F5 with the addition of different amounts of oregano and basil extracts in combination, F6 (control formulation) without natural (extracts) or synthetic antioxidants, and F7 with the addition of the synthetic antioxidant BHT. A total of $4 \mathrm{~kg}$ was prepared for each formulation, totaling $28 \mathrm{~kg}$ of product, corresponding to about 40 sausages of $100 \mathrm{~g}$ per formulation. The concentrations of extracts were defined from tests previously carried out. 
Table 1

Formulations of linguiça calabresa (traditional Brazilian sausage) with the addition of oregano extract $(\mathrm{OE})$, basil extract (BE), and synthetic antioxidant, butylated hydroxytoluene (BHT)

\begin{tabular}{|cccccccc|}
\hline Ingredients (\%) & F1 & F2 & F3 & F4 & F5 & F6 & F7 \\
\hline Pork meat (palette and fat flap) & 78.53 & 78.28 & 78.28 & 78.53 & 78.28 & 78.53 & 78.28 \\
\hline Fat (bacon) & 10.00 & 10.00 & 10.00 & 10.00 & 10.00 & 10.00 & 10.00 \\
\hline Water / ice & 5.00 & 5.00 & 5.00 & 5.00 & 5.00 & 5.00 & 5.00 \\
Salt & 1.80 & 1.80 & 1.80 & 1.80 & 1.80 & 1.80 & 1.80 \\
Curing salt & 0.20 & 0.20 & 0.20 & 0.20 & 0.20 & 0.20 & 0.20 \\
Sodium erythorbate & 0.20 & 0.20 & 0.20 & 0.20 & 0.20 & 0.20 & 0.20 \\
Sugar & 0.13 & 0.13 & 0.13 & 0.13 & 0.13 & 0.13 & 0.13 \\
Monosodium glutamate & 0.10 & 0.10 & 0.10 & 0.10 & 0.10 & 0.10 & 0.10 \\
Calabrian pepper & 0.06 & 0.06 & 0.06 & 0.06 & 0.06 & 0.06 & 0.06 \\
Sodium tripolyphosphate & 0.20 & 0.20 & 0.20 & 0.20 & 0.20 & 0.20 & 0.20 \\
BE & 0.05 & 0.05 & 0.1 & 0.075 & 0.1 & ---- & ---- \\
OE & 0.05 & 0.1 & 0.05 & 0.075 & 0.1 & ---- & ---- \\
BHT & ---- & ---- & ---- & ---- & ---- & ---- & 0.01
\end{tabular}

Sausages (linguiça calabresa) were prepared using only pork (pork cuts and fat) as raw material. It was purchased from a slaughterhouse located in southwestern Paraná State. First, pork was weighed, ground using an $8 \mathrm{~mm}$ plate, and mixed with the other ingredients. Then, the material was homogenized and divided into rolls of about $100 \mathrm{~g}$ each. The sausages were oven-cooked at $60{ }^{\circ} \mathrm{C}$ for $3 \mathrm{~h}$ and $15 \mathrm{~min}$, increasing the temperature by $5^{\circ} \mathrm{C}$ every $1 \mathrm{~h}$ until the internal temperature reached $75{ }^{\circ} \mathrm{C}$. All formulations were subjected to cold smoking with natural smoke, cooled, vacuum-packed (Selovac Sealer, Selovac, Brazil) in five-layered polynylon bags, and stored at $4^{\circ} \mathrm{C}$ until analysis.

\section{Determination of proximate composition, $\mathrm{pH}$, acidity and water activity}

Proximate chemical composition was determined according to AOAC International methods (AOAC, 1995). Briefly, moisture was determined by drying (Oven ASL 102, Solab, Brazil) at $105{ }^{\circ} \mathrm{C}$; ash, by incineration in a muffle furnace (Quimis, Q318M25T, Brazil) at $550{ }^{\circ} \mathrm{C}$; and lipids, by Soxhlet extraction with petroleum ether after acid hydrolysis. Nitrogen content was ascertained by the micro-Kjeldahl method, using a protein conversion factor of 6.25 , and carbohydrate content was calculated by difference.

The analyses of $\mathrm{pH}$, water activity, and acidity were performed at 4 and 53 days of storage at $4{ }^{\circ} \mathrm{C}$. The $\mathrm{pH}$ was determined using a pH meter (Testo 205, Testo, Germany), while water activity was assessed using Aqualab 4TEV equipment (4 TEV, AquaLab, USA). Acidity was determined by titration with 0.1 mol $\mathrm{L}^{-1} \mathrm{NaOH}$, according to the Adolfo Lutz Institute method (Instituto Adolfo Lutz [IAL, 2008]). 


\section{Lipid oxidation}

Lipid oxidation was evaluated after 4 17,31 , and 53 days of storage at $4{ }^{\circ} \mathrm{C}$ by the thiobarbituricacidreactivesubstances(TBARS) method, as described by Tarladgis, Pearson, \& Dugan Jun (1964), with modifications. Briefly, $5.0 \mathrm{~g}$ of the sausage was homogenized with $15.0 \mathrm{~mL}$ of $7.5 \%(\mathrm{w} / \mathrm{v})$ trichloroacetic acid and $2.0 \mathrm{~mL}$ of $20 \%$ sulfanilamide, using a Turrax mixing device (Turratec TE-102, Tecnal, Brazil) at $7000 \mathrm{rpm}$ for $2 \mathrm{~min}$, centrifuged (Eppendorf, $5810 \mathrm{R}$, Germany) at $6000 \mathrm{rpm}$ and $20^{\circ} \mathrm{C}$ for $10 \mathrm{~min}$, and filtered through filter paper. A 5.0 $\mathrm{mL}$ aliquot of the filtrate was mixed with $5.0 \mathrm{~mL}$ of $0.02 \mathrm{~mol} \mathrm{~L}^{-1}$ thiobarbituric acid, incubated in a boiling water bath for $35 \mathrm{~min}$, cooled to room temperature, and read on a spectrophotometer (Libra S22, Biochrom, England) at $532 \mathrm{~nm}$. A standard curve of 1,1,3,3-tetraethoxypropane in $1 \%$ sulfuric acid was constructed in the concentration range of 0.4 to $3.6 \times 10^{-3}$ $\mathrm{mmol} \mathrm{L}^{-1}$. Results were expressed in $\mathrm{mg}$ of malonaldehyde $\mathrm{kg}^{-1}$ sample.

\section{Color and texture analysis}

Color measurements were performed after $4,17,31$, and 53 days of storage at 4 ${ }^{\circ} \mathrm{C}$ on a colorimeter (Minolta CR-400, Konica Minolta, Japan) set up for illuminant D65 and $10^{\circ}$ observer angle. Sausage samples were analyzed at three different points on the inside of each slice. Results were expressed in CIELAB coordinates $\left(L^{*}, a^{*}\right.$, and $\left.b^{*}\right)$.

Texture profile analysis was carried out after 5 and 54 days of storage, using a TA.XTplus analyzer (Stable Micro Systems, UK) (Bourne, 1978). The analyzed parameters were as follows: pre-test speed of $2 \mathrm{~mm} \mathrm{~s}^{-1}$, test speed of $4 \mathrm{~mm} \mathrm{~s}^{-1}$, post-test speed of
$10 \mathrm{~mm} \mathrm{~s}^{-1}$, force of $0.1 \mathrm{~N}$, analysis time of $5 \mathrm{~s}$, and compression distance of $5 \mathrm{~mm}$. Sausage samples were cut into cylindrical slices $(2 \mathrm{~cm}$ height) and compressed twice to $50 \%$ of their height, using a P/40 probe. Lastly, hardness (N), adhesiveness (N.s), cohesiveness, springiness, chewiness $(\mathrm{N})$, and resilience were determined.

\section{Statistical analysis}

Data were subjected to analysis of variance (ANOVA) followed by Tukey's mean test at the $5 \%$ significance level, using Statistica software version 7.0 (StatSoft, 2005).

\section{Results and Discussion}

Antioxidant activity of oregano and basil extracts

Moisture contents of the spices were $11.98 \%( \pm 0.15 \%)$ in oregano and $11.93 \%$ $( \pm 0.09 \%)$ in basil, both following the Brazilian legislation (Agência Nacional de Vigilância Sanitária [ANVISA, 2005]), in which a maximum of $12 \%$ is required to conserve bioactive compounds.

Oregano extract was obtained at a higher yield $(p<0.05)$ and showed higher antioxidant activity than did basil extract by all methods (Table 2). This may be due to a greater presence of soluble antioxidant compounds in the hydroalcoholic solution of oregano leaves. Other authors have also found that oregano had high antioxidant activity likely associated with its high concentration of phenolic compounds (Alezandro, Lui, Lajolo, \& Genovese, 2011; Gonçalves et al., 2015; Fernandes et al., 2016a). 
Table 2

Yield and antioxidant activity of oregano and basil lyophilized extracts

\begin{tabular}{|c|c|c|c|}
\hline \multirow{2}{*}{ Methods } & \multicolumn{3}{|c|}{ Extracts } \\
\hline & Oregano & Basil & BHT \\
\hline Extract yield (\%) & 17.30 & 8.17 & - \\
\hline $\begin{array}{c}\text { DPPH EC }_{50} \\
\text { (g extract g-1 DPPH) }\end{array}$ & $29.75^{b} \pm 2.81$ & $40.50^{a} \pm 4.66$ & $42.73^{a} \pm 3.61$ \\
\hline $\begin{array}{c}\text { FRAP } \\
\text { (mmol Trolox } \mathrm{g}^{-1} \text { extract) }\end{array}$ & $2935.52^{a} \pm 99.83$ & $1358.39^{b} \pm 26.17$ & N.A \\
\hline $\begin{array}{c}\text { ABTS } \\
\text { (mmol Trolox } \mathrm{g}^{-1} \text { extract) }\end{array}$ & $2.58^{a} \pm 0.15$ & $0.71^{b} \pm 0.02$ & N.A \\
\hline $\begin{array}{l}\text { Reducing capacity } \\
\text { (g GAE g }{ }^{-1} \text { extract) }\end{array}$ & $199.39^{a} \pm 7.64$ & $103.26^{b} \pm 8.75$ & N.A \\
\hline
\end{tabular}

N.A: not analyzed.

a-b Same letters in the line indicate no difference between extracts (Tukey, $p>0.05$ ).

When comparing oregano and basil extracts by the Folin-Ciocalteu method, oregano showed a reducing capacity of $199.39 \mathrm{~g} \mathrm{GAE} \mathrm{g}^{-1}$ extract, while basil had $103.26 \mathrm{~g} \mathrm{GAE} \mathrm{g}^{-1}$ extract. Gonçalves et al. (2015) demonstrated that basil and oregano alcoholic extracts had reducing capacities of 7.0 and $41.0 \mu \mathrm{g} \mathrm{GAE} \mathrm{mL}^{-1}$, respectively.

By the ABTS method, oregano extract had 3.6 times more antioxidant activity than did basil extract, showing values of 2.58 and 0.71 mmol Trolox $\mathrm{g}^{-1}$ extract, respectively. Mariutti Barreto, Bragagnolo and Mercadante (2008) found that oregano and basil ethanol extracts had ABTS values of 73.3 and $8.6 \mathrm{mmol}$ Trolox $\mathrm{g}^{-1}$, respectively.

Oregano extracts also showed better results than did basil extracts by the FRAP method, with values of 2935.52 and 1358.39 mmol Trolox $\mathrm{g}^{-1}$ extract, respectively. By using the same method, Fernandes et al. (2016a) observed that oregano extract had an antioxidant activity of $472.32 \mu \mathrm{mol}$ Trolox $\mathrm{g}^{-1}$ dry weight and basil extract $213.28 \mu \mathrm{mol}$
Trolox $\mathrm{g}^{-1}$ dry weight. In the study of Fernandes, Trindade, Lorenzo, Munekata and Melo (2016b), oregano extract had a FRAP value of 344.09 mmol Trolox $\mathrm{g}^{-1}$ and, in general, its phenolic profile showed a positive correlation with its antioxidant activity.

Regarding the DPPH method, oregano extracts showed lower EC50 values $(29.75 \mathrm{~g}$ extract $\left.^{-1} \mathrm{DPPH}\right)$ than did basil extracts $(40.50 \mathrm{~g}$ extract g-1 DPPH); therefore, a smaller amount of oregano extract is needed to decrease the initial concentration of DPPH radical by $50 \%$. Alezandro et al. (2011) found that oregano extract has higher DPPH radical-scavenging activity and total phenolic contents than do basil, bay leaf, chive, parsley, onion, rosemary, and turmeric extracts.

As mentioned before, the referred studies revealed that oregano extracts have stronger antioxidant activity and reducing capacity than do basil extracts, thus agreeing with our findings. However, our values were relatively higher for FRAP, ABTS, and reducing capacity methods and lower for EC50 
(DPPH method). This might be due to extract preparation for freeze-drying different from others authors.

By comparing the DPPH antioxidant activities of natural and synthetic (BHT) extracts, the $\mathrm{EC}_{50}$ of $\mathrm{BHT}$ was like that of basil extract and 1.6 times higher than that of oregano extract (Table 2). The extracts were evaluated for antioxidant activity during storage (Figure 1). The results showed that activity decreased over time, by $37.32 \%$ for oregano and $51.36 \%$ for basil, after 39 days of storage at $-18^{\circ} \mathrm{C}$. Bhale et al. (2007) observed that oregano extract is more stable and resistant to high cooking temperatures than is rosemary extract. In this sense, oregano extract can be used in cooked meat products such as linguiça calabresa.

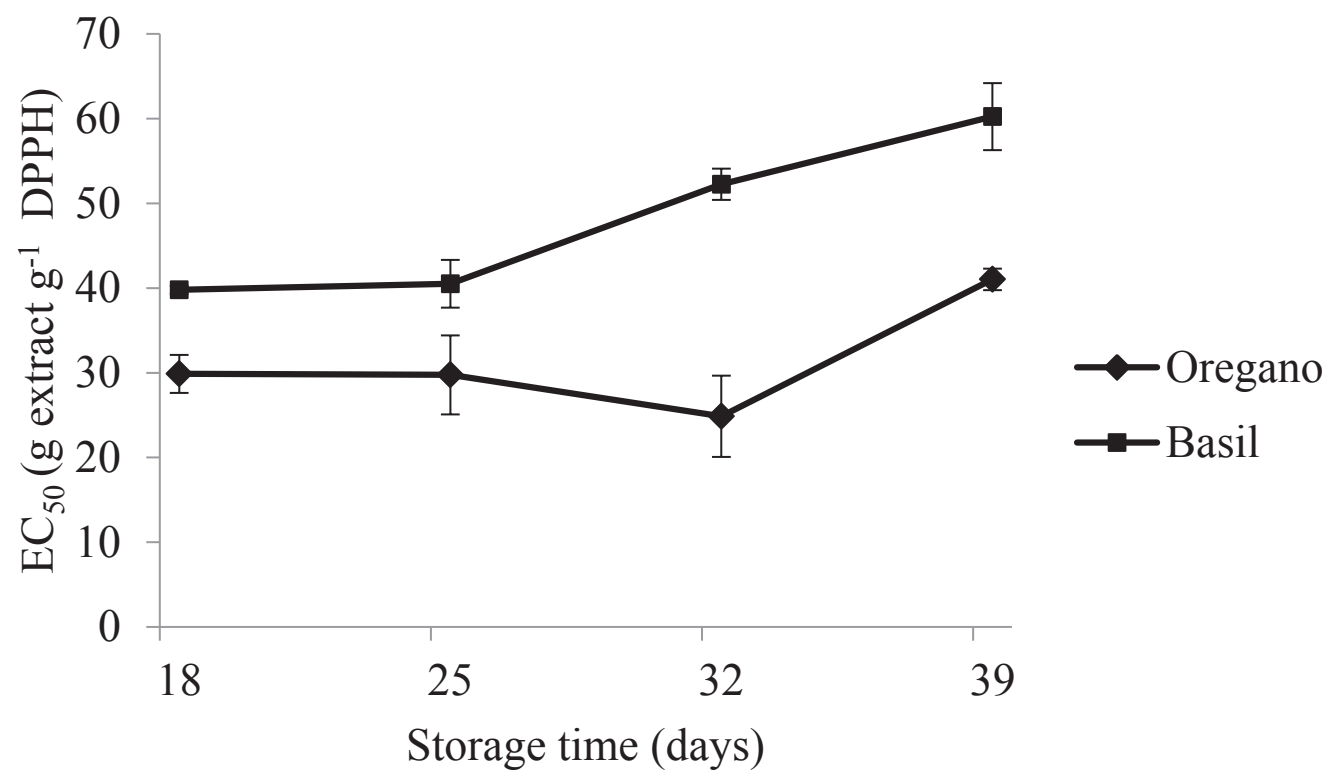

Figure 1. Evaluation of antioxidant activity by the DPPH radical capture method during storage of hydroalcoholic extracts of oregano, and basil for 39 days at $-18^{\circ} \mathrm{C}$.

\section{Proximate composition, $\mathrm{pH}$, acidity and water} activity

Sausage formulations did not differ $(p>0.05)$ in chemical composition (Table 3). All formulations were under the
Brazilian legislation, having a maximum lipid concentration of $35 \%$, a maximum moisture content of $60 \%$, and a minimum protein content of $14 \%$ (Ministério da Agricultura Pecuária e Abastecimento [MAPA], 2000). 
Table 3

Approximate chemical composition of linguiças calabresas (traditional Brazilian sausage) formulated with the addition of oregano and basil extracts

\begin{tabular}{|cccccc|} 
Formulations & Lipids (\%) & Proteins (\%) & Moisture (\%) & Ashes (\%) & Carbohydrates* $(\%)$ \\
\hline F1 & $12.85^{\mathrm{a}} \pm 2.22$ & $18.88^{\mathrm{a}} \pm 2.80$ & $55.17^{\mathrm{a}} \pm 4.69$ & $6.83^{\mathrm{a}} \pm 2.06$ & 6.25 \\
\hline F2 & $13.56^{\mathrm{a}} \pm 2.14$ & $20.69^{\mathrm{a}} \pm 2.10$ & $59.48^{\mathrm{a}} \pm 0.74$ & $4.73^{\mathrm{a}} \pm 2.94$ & 1.53 \\
\hline F3 & $13.43^{\mathrm{a}} \pm 9.95$ & $20.27^{\mathrm{a}} \pm 3.01$ & $55.94^{\mathrm{a}} \pm 3.17$ & $4.83^{\mathrm{a}} \pm 3.15$ & 5.51 \\
\hline F4 & $14.56^{\mathrm{a}} \pm 4.58$ & $21.02^{\mathrm{a}} \pm 1.67$ & $56.28^{\mathrm{a}} \pm 1.50$ & $6.87^{\mathrm{a}} \pm 1.32$ & 1.27 \\
\hline F5 & $15.26^{\mathrm{a}} \pm 3.32$ & $21.20^{\mathrm{a}} \pm 2.46$ & $57.06^{\mathrm{a}} \pm 1.21$ & $4.74^{\mathrm{a}} \pm 3.26$ & 1.73 \\
\hline F6 & $17.53^{\mathrm{a}} \pm 3.33$ & $20.54^{\mathrm{a}} \pm 1.84$ & $55.16^{\mathrm{a}} \pm 2.73$ & $6.50^{\mathrm{a}} \pm 1.44$ & 0.26 \\
\hline F7 & $14.95^{\mathrm{a}} \pm 3.87$ & $21.46^{\mathrm{a}} \pm 0.94$ & $55.20^{\mathrm{a}} \pm 1.00$ & $7.47^{\mathrm{a}} \pm 0.31$ & 0.91
\end{tabular}

F1: $0.05 \%$ oregano extract / $0.05 \%$ basil extract; F2: $0.1 \%$ oregano extract / $0.05 \%$ basil extract; F3: $0.05 \%$ oregano extract / 0.1\% basil extract; F4: $0.075 \%$ oregano extract / $0.075 \%$ basil extract; F5: $0.1 \%$ oregano extract / $0.1 \%$ basil extract; F6: Control; F7: 0.01\% BHT.

a Same letter in the column indicate no difference between the formulations (Tukey, p > 0.05).

* Carbohydrate is calculated by difference.

The studied formulations also differed in $\mathrm{pH}(6.27$ to 6.43$)(p<0.05)$ during storage (Table 4). Alves et al. (2016) found that Bologna sausages have a $\mathrm{pH}$ range of 6.01 to 6.11. Changes in $\mathrm{pH}$ during storage were also observed by Barbosa, Clemente, Chaves, Fonseca and Meireles (2019) (6.33 to 5.02) and Zago et al. (2020) (5.66 to 6.16) for sausages prepared with fresh bovine meat, rosemary extract, and green tea ( 45 days at $0-4{ }^{\circ} \mathrm{C}$ ) and Tuscan sausage prepared with freezedried pomegranate peel extract (30 days at $\left.5{ }^{\circ} \mathrm{C}\right)$, respectively. The $\mathrm{pH}$ values recorded in the current study remained close to the acceptable limits for meat products $(\mathrm{pH} 5.4$ to 6.2) (Mantovani, Corazza, Cardozo, \& Costa, 2011). F5 and F6 showed higher pH values ( $p<$ 0.05 ) at 53 days of storage, whereas F1 and F3 had lower $(p<0.05)$. The gradual reduction in $\mathrm{pH}$ was due to a lower temperature of storage $\left(4^{\circ} \mathrm{C}\right.$ ), vacuum packaging (barrier to $\mathrm{O}_{2}$ ), and the development of lactic acid bacteria, which increases product acidity (Zago, 2018). Schwert (2009) also verified a reduction in $\mathrm{pH}$ for linguiça calabresa (60 days) due to lactic acid.

No significant differences $(p>0.05)$ in acidity (Table 4) were observed among sausage formulations at 4 (4.08-4.81\%) and 53 (4.60$5.65 \%)$ days of storage; however, it increased $(p<0.05)$ for F3, F4, and F6 at the end of the 53-day storage period. A similar increase in acidity was also reported by Joseph, Chatli, Biswas and Sahoo (2014) for pork emulsion containing tomato products and/or guava pulp and stored at $4^{\circ} \mathrm{C}$ for 9 days. Such an increase can be attributed to the formation of organic acids, such as lactic acid (Carbonera \& Espírito Santo, 2010). 
Table 4

Parameters of $\mathrm{pH}$, acidity and water activity of linguiças calabresas (traditional Brazilian sausage) formulated with the addition of oregano and basil extracts

\begin{tabular}{|c|c|c|c|c|}
\hline \multirow[b]{2}{*}{ Days } & \multirow[b]{2}{*}{ Formulations } & \multicolumn{3}{|c|}{ Parameters } \\
\hline & & $\mathrm{pH}$ & Acidity (\%) & Water activity \\
\hline \multirow{7}{*}{04} & F1 & $6.40^{\mathrm{aA}} \pm 0.01$ & $4.64^{\mathrm{aA}} \pm 0.34$ & $0.96^{\mathrm{aA}} \pm 0.01$ \\
\hline & $\mathrm{F} 2$ & $6.41^{\mathrm{aA}} \pm 0.02$ & $4.79^{\mathrm{aA}} \pm 0.41$ & $0.96^{\mathrm{aA}} \pm 0.01$ \\
\hline & F3 & $6.36^{\mathrm{abA}} \pm 0.03$ & $4.62^{\mathrm{aB}} \pm 0.15$ & $0.96^{\mathrm{ab}} \pm 0.00$ \\
\hline & F4 & $6.34^{\mathrm{bA}} \pm 0.02$ & $4.69^{a \mathrm{~B}} \pm 0.42$ & $0.97^{\mathrm{aA}} \pm 0.01$ \\
\hline & F5 & $6.34^{\mathrm{bB}} \pm 0.05$ & $4.8 \mathrm{~A}^{\mathrm{aA}} \pm 0.25$ & $0.97^{\mathrm{aA}} \pm 0.00$ \\
\hline & F6 & $6.37^{\mathrm{abB}} \pm 0.01$ & $4.08^{\mathrm{aB}} \pm 0.39$ & $0.98^{\mathrm{aA}} \pm 0.00$ \\
\hline & F7 & $6.33^{\mathrm{bA}} \pm 0.04$ & $4.31^{\mathrm{aA}} \pm 0.40$ & $0.97^{\mathrm{aA}} \pm 0.00$ \\
\hline \multirow{7}{*}{53} & F1 & $6.28^{\mathrm{bB}} \pm 0.01$ & $5.46^{\mathrm{aA}} \pm 0.18$ & $0.97^{\mathrm{aA}} \pm 0.00$ \\
\hline & $\mathrm{F} 2$ & $6.38^{\mathrm{abA}} \pm 0.01$ & $4.83^{\mathrm{aA}} \pm 0.38$ & $0.97^{\mathrm{aA}} \pm 0.00$ \\
\hline & F3 & $6.27^{\mathrm{bB}} \pm 0.03$ & $5.65^{\mathrm{aA}} \pm 0.19$ & $0.97^{\mathrm{aA}} \pm 0.00$ \\
\hline & F4 & $6.37^{\mathrm{abA}} \pm 0.08$ & $5.64^{\mathrm{aA}} \pm 0.55$ & $0.97^{\mathrm{aA}} \pm 0.01$ \\
\hline & F5 & $6.43^{\mathrm{aA}} \pm 0.02$ & $4.92^{\mathrm{aA}} \pm 0.34$ & $0.97^{\mathrm{aA}} \pm 0.01$ \\
\hline & F6 & $6.39^{\mathrm{abA}} \pm 0.01$ & $4.91^{\mathrm{aA}} \pm 0.13$ & $0.97^{\mathrm{aA}} \pm 0.00$ \\
\hline & F7 & $6.35^{\mathrm{abA}} \pm 0.03$ & $4.60^{\mathrm{aA}} \pm 0.37$ & $0.97^{\mathrm{aA}} \pm 0.00$ \\
\hline
\end{tabular}

F1: $0.05 \%$ oregano extract / $0.05 \%$ basil extract; F2: $0.1 \%$ oregano extract / $0.05 \%$ basil extract; F3: $0.05 \%$ oregano extract / $0.1 \%$ basil extract; F4: $0.075 \%$ oregano extract / $0.075 \%$ basil extract; F5: $0.1 \%$ oregano extract / $0.1 \%$ basil extract; F6: Control; F7: 0.01\% BHT.

a-b Same lowercase letters in the column indicate that there is no difference between the formulations (Tukey, $p>0.05$ ).

A-B Same capital letters in the column indicate that there is no difference between the days evaluated for the same formulation (Tukey, $p>0.05$ ).

All sausage formulations did not differ $(p>0.05)$ in water activity throughout storage (Table 4), ranging from 0.96 to 0.98. Similar results were reported by Alves et al. (2016) (0.97 to 0.98) for Bologna sausage and lower values were obtained by Castellucci (2004) for vacuum-packed linguiça calabresa (0.95).

\section{Lipid oxidation}

Lipid oxidation ranged from 0.27 to $0.39 \mathrm{mg}$ malonaldehyde $\mathrm{kg}^{-1}$ (Table 5), that is, lower than the human threshold for detection of unpleasant odor (0.5-1.0 mg malonaldehyde $\mathrm{kg}^{-1}$ ), as reported by De Carli, Terra, Fries, Menezes and Palezi (2013). Values lower than $0.5 \mathrm{mg}$ malonaldehyde $\mathrm{kg}^{-1}$ were also found by Zago et al. (2020) and Boeira et al. (2020) for Tuscan sausage prepared with freezedried pomegranate peel extract after 30 days of storage and fresh chicken sausage with lemongrass extract after 42 days of storage, respectively. 


\section{Table 5}

Lipid oxidation (mg malonaldehyde $\mathrm{kg}^{-1}$ sample) of linguiça calabresa (traditional Brazilian sausage) formulated with the addition of oregano and basil extracts

Formulations
F1

F2

F3

F4

F5

F6

F7
4

$0.28^{\mathrm{aB}} \pm 0.00$

$0.28^{\mathrm{aB}} \pm 0.01$

$0.32^{\mathrm{aAB}} \pm 0.02$

$0.31^{\mathrm{aB}} \pm 0.03$

$0.31^{\mathrm{aB}} \pm 0.02$

$0.28^{\mathrm{aC}} \pm 0.02$

$0.27^{\mathrm{aB}} \pm 0.02$
Days of storage at $4{ }^{\circ} \mathrm{C}$

17

$0.36^{\mathrm{aA}} \pm 0.03$

$0.35^{\mathrm{aA}} \pm 0.00$

$0.36^{\mathrm{aA}} \pm 0.00$

$0.37^{\mathrm{aA}} \pm 0.01$

$0.38^{\mathrm{aA}} \pm 0.01$

$0.35^{\mathrm{aAB}} \pm 0.02$

$0.28^{\mathrm{bB}} \pm 0.02$

\section{1}

$0.37^{\mathrm{abA}} \pm 0.01$

$0.36^{\mathrm{bA}} \pm 0.01$

$0.36^{\mathrm{abA}} \pm 0.00$

$0.39^{\mathrm{abA}} \pm 0.01$

$0.39^{\mathrm{aA}} \pm 0.02$

$0.37^{\mathrm{abA}} \pm 0.02$

$0.38^{\mathrm{abA}} \pm 0.01$
53

$0.29^{\mathrm{bcB}} \pm 0.02$

$0.31^{\mathrm{bcB}} \pm 0.01$

$0.31^{\mathrm{bcB}} \pm 0.01$

$0.37^{\mathrm{aA}} \pm 0.03$

$0.35^{\mathrm{abAB}} \pm 0.02$

$0.31^{\mathrm{abcBC}} \pm 0.01$

$0.27^{\mathrm{CB}} \pm 0.02$

F1: $0.05 \%$ oregano extract / $0.05 \%$ basil extract; F2: $0.1 \%$ oregano extract / $0.05 \%$ basil extract; F3: $0.05 \%$ oregano extract / $0.1 \%$ basil extract; F4: $0.075 \%$ oregano extract / $0.075 \%$ basil extract; $F 5: 0.1 \%$ oregano extract / $0.1 \%$ basil extract; F6: Control; F7: 0.01\% BHT.

a-c Same lowercase letters in the column indicate that there is no difference between the formulations (Tukey, $p>0.05$ ).

A-C Same capital letters in the line indicate that there is no difference between the days evaluated for the same formulation (Tukey, $\mathrm{p}>0.05$ ).

An increase in lipid oxidation reactions was detected at 17 days of storage (Table 5). After this period, the level of oxidation varied between formulations and storage days. F7, which was prepared with $\mathrm{BHT}$, was stable ( $p$ $>0.05$ ) up to 17 days of storage. During the evaluation period, changes in TBARS values were observed in all formulations, which evidences oxidative reactions. Schwert, Verlindo, Cichoski, Oliveria and Valduga (2011) found that variations in TBARS values during storage are associated with reactions between malonaldehyde and several other compounds. Kim, Cho and Han (2013) also reported significant changes in TBARS values between treatments and storage times (total of 12 days) for meat products prepared with plant extracts.

By comparing the formulations added with natural extracts, F5 was the only to maintain the levels of lipid oxidation between
17 to 53 days, while the TBARS values of F1, F2, F3, and F4 increased between 4 and 17 days of storage, stabilized between 17 and 31 days, and then decreased between 31 and 53 days. This behavior is typical of some products from lipid oxidation, such as thiobarbituric acid reactive compounds, whose values, in most cases, increase during storage, reaching a maximum value and, subsequently, decreasing or stabilizing, due to secondary reactions of malonaldehyde (Channon \& Trout, 2002). Utrera and Estévez (2013) observed reductions in hexanal contents in different types of meat and correlated it to increasing Schiff bases, suggesting reactions between aldehydes (lipid oxidation products) and proteins. At 53 days of storage, F3, F2, and F1 had the lowest lipid oxidation values and did not differ $(p>0.05)$ from the control (F6) and the formulation with synthetic antioxidant (F7). Therefore, these findings indicate that these formulations had reduced lipid oxidation. 
Although basil and oregano extracts showed good antioxidant activity, their concentrations and activities together did not significantly inhibit lipid oxidation in linguiça calabresa formulations. However, these extracts can be used in the food industry as natural antioxidants, as they showed antioxidant activity similar to BHT after one month of storage. The formulations added with natural extracts (F1, F2, and F3) showed similar efficiency to that using synthetic antioxidant BHT (F7). Still, F1 showed similar results to the control formulation for color and texture analyses.

The results of lipid oxidation indicate that further studies with variations in extract concentrations are needed. This is because extracts may have different antioxidant activities if used individually, in fresh or nonvacuum-packed products. Furthermore, the reduction of oxygen in packaging may have inhibited lipid oxidation reactions in all formulations, making it difficult to analyze the data obtained. These varied in a relatively small range and below the limits of human detection (0.5-1.0 mg malonaldehyde $\mathrm{kg}^{-1}$ sample) (De Carli et al., 2013).

\section{Color parameters and texture profile}

Sausage formulations did not differ ( $p$ $>0.05$ ) in $L^{*}$ (lightness) during storage (Table 6). This is a good result, as a decrease in $L^{*}$ indicates darkening, stemming from chemical reactions and dehydration (Lorenzo, GonzálezRodríguez, Sánchez, Amado, \& Franco, 2013). Bozkurt and Bayram (2006) and Lorenzo, Temperán, Bermúdez, Cobas, \& Purriños (2012) observed that the $L^{*}$ values of meat sausages decreased during curing at 15 and 28 days, respectively.

F1, F2, F6, and F7 (Table 6) always had higher $a^{*}$ (red-green component) and lower $b^{*}$ (yellow-blue component) values, which are desirable for meat products (Zago, 2018). Together with F3, these formulations showed the best results for lipid oxidation and kept red color intensity, reducing iron oxidation in myoglobin. The parameter $a^{*}$ ranged from 10.93 to 13.97 during storage, with significant differences $(p<0.05)$ between $\mathrm{F} 2$ and the other formulations. F3 and F5 had higher $(p<0.05)$ $b^{*}$ values, indicating a tendency to yellowing. This is likely related to the presence of basil and oregano extracts. Krishnan et al. (2014) and Karabagias, Badeka and Kontominas (2011) also observed increases ( $p<0.05$ ) in $b^{*}$ values in chicken fillet prepared with spice extracts and lamb meat prepared with oregano essential oil, respectively. The color parameters of F6 (control) and F7 (BHT) were closer to those of F1. 
Table 6

Color parameters, lightness ( $\left.L^{*}\right)$, red-green component ( $a^{*}$ ) and yellow-blue component ( $\left.b^{*}\right)$, of linguiças calabresas (traditional Brazilian sausage) formulated with the addition of oregano and basil extracts

\begin{tabular}{|c|c|c|c|c|}
\hline Days & Formulations & $L^{*}$ & $a^{*}$ & $b^{*}$ \\
\hline \multirow{7}{*}{04} & F1 & $58.74^{\mathrm{aA}} \pm 1.83$ & $13.17^{\mathrm{aA}} \pm 1.06$ & $6.53^{\mathrm{abcA}} \pm 0.54$ \\
\hline & $\mathrm{F} 2$ & $59.39^{\mathrm{aA}} \pm 1.97$ & $11.60^{\mathrm{bB}} \pm 1.00$ & $6.23^{\mathrm{bcB}} \pm 0.50$ \\
\hline & F3 & $58.96^{\mathrm{aA}} \pm 3.30$ & $11.57^{\mathrm{bA}} \pm 1.17$ & $6.99^{\mathrm{abA}} \pm 0.60$ \\
\hline & F4 & $59.40^{\mathrm{aA}} \pm 1.10$ & $11.71^{\mathrm{bA}} \pm 0.26$ & $6.42^{\mathrm{bcB}} \pm 0.42$ \\
\hline & F5 & $58.83^{\mathrm{aA}} \pm 2.11$ & $11.45^{\mathrm{bA}} \pm 0.99$ & $7.42^{\mathrm{aA}} \pm 0.68$ \\
\hline & F6 & $58.95^{\mathrm{aA}} \pm 2.08$ & $13.81^{\mathrm{aA}} \pm 0.89$ & $5.94^{\mathrm{cdA}} \pm 0.66$ \\
\hline & F7 & $59.09^{\mathrm{aA}} \pm 3.64$ & $13.64^{\mathrm{aA}} \pm 1.02$ & $5.17^{\mathrm{dc}} \pm 0.55$ \\
\hline \multirow{7}{*}{17} & $\mathrm{~F} 1$ & $60.76^{\mathrm{aA}} \pm 2.18$ & $12.18^{\mathrm{aA}} \pm 1.17$ & $6.61^{\mathrm{abcA}} \pm 0.63$ \\
\hline & $\mathrm{F} 2$ & $56.70^{\mathrm{aA}} \pm 2.56$ & $12.99^{\mathrm{aA}} \pm 1.28$ & $6.12^{\mathrm{bcB}} \pm 0.58$ \\
\hline & F3 & $58.98^{\mathrm{aA}} \pm 2.71$ & $12.17^{\mathrm{aA}} \pm 0.93$ & $7.30^{\mathrm{aA}} \pm 0.84$ \\
\hline & $\mathrm{F} 4$ & $57.33^{\mathrm{aB}} \pm 1.64$ & $12.28^{\mathrm{aA}} \pm 1.03$ & $7.00^{\mathrm{abA}} \pm 0.42$ \\
\hline & F5 & $57.60^{\mathrm{aA}} \pm 2.17$ & $11.24^{\mathrm{aA}} \pm 1.58$ & $7.40^{\mathrm{aA}} \pm 0.78$ \\
\hline & F6 & $59.88^{\mathrm{aA}} \pm 4.45$ & $13.35^{\mathrm{aA}} \pm 1.68$ & $6.11^{\mathrm{bcA}} \pm 0.53$ \\
\hline & F7 & $60.14^{\mathrm{aA}} \pm 2.29$ & $13.03^{\mathrm{aA}} \pm 1.08$ & $5.94^{\mathrm{CB}} \pm 0.38$ \\
\hline \multirow{7}{*}{31} & $\mathrm{~F} 1$ & $58.60^{\mathrm{aA}} \pm 1.87$ & $12.55^{\mathrm{abcA}} \pm 1.14$ & $6.67^{\mathrm{bcA}} \pm 0.59$ \\
\hline & F2 & $57.93^{\mathrm{aA}} \pm 1.82$ & $11.91^{\mathrm{bCdAB}} \pm 0.88$ & $7.16^{\mathrm{abA}} \pm 0.65$ \\
\hline & F3 & $58.93^{\mathrm{aA}} \pm 2.10$ & $11.50^{\mathrm{bcdA}} \pm 1.01$ & $7.42^{\mathrm{aA}} \pm 0.74$ \\
\hline & F4 & $58.31^{\mathrm{aAB}} \pm 1.16$ & $11.43^{\mathrm{bcdA}} \pm 0.67$ & $7.45^{\mathrm{aA}} \pm 0.34$ \\
\hline & F5 & $59.84^{\mathrm{aA}} \pm 2.59$ & $10.93^{\mathrm{dA}} \pm 1.04$ & $7.75^{\mathrm{aA}} \pm 0.70$ \\
\hline & F6 & $59.59^{\mathrm{aA}} \pm 3.36$ & $13.97^{\mathrm{aA}} \pm 1.16$ & $6.33^{\mathrm{cA}} \pm 0.48$ \\
\hline & F7 & $59.29^{\mathrm{aA}} \pm 2.09$ & $13.07^{\mathrm{abA}} \pm 1.24$ & $6.40^{\mathrm{cAB}} \pm 0.34$ \\
\hline \multirow{7}{*}{53} & $\mathrm{~F} 1$ & $58.67^{\mathrm{aA}} \pm 3.19$ & $12.62^{\mathrm{abA}} \pm 1.13$ & $6.79^{\mathrm{bcA}} \pm 0.66$ \\
\hline & $\mathrm{F} 2$ & $59.12^{\mathrm{aA}} \pm 3.46$ & $12.52^{\mathrm{abAB}} \pm 1.13$ & $7.11^{\mathrm{abA}} \pm 0.59$ \\
\hline & F3 & $59.27^{\mathrm{aA}} \pm 3.25$ & $11.53^{\mathrm{bA}} \pm 0.97$ & $7.51^{\mathrm{abA}} \pm 0.51$ \\
\hline & F4 & $59.23^{\mathrm{aA}} \pm 1.27$ & $11.75^{\mathrm{bA}} \pm 0.71$ & $7.19^{\mathrm{abA}} \pm 0.44$ \\
\hline & F5 & $58.13^{\mathrm{aA}} \pm 2.36$ & $11.82^{\mathrm{bA}} \pm 1.16$ & $7.89^{\mathrm{aA}} \pm 0.26$ \\
\hline & F6 & $59.76^{\mathrm{aA}} \pm 3.48$ & $13.70^{\mathrm{aA}} \pm 1.22$ & $5.87^{\mathrm{CA}} \pm 0.42$ \\
\hline & F7 & $59.93^{\mathrm{aA}} \pm 1.99$ & $12.44^{\mathrm{abA}} \pm 1.07$ & $6.79^{\mathrm{bcA}} \pm 0.59$ \\
\hline
\end{tabular}

F1: $0.05 \%$ oregano extract / $0.05 \%$ basil extract; F2: $0.1 \%$ oregano extract / $0.05 \%$ basil extract; F3: $0.05 \%$ oregano extract / $0.1 \%$ basil extract; F4: $0.075 \%$ oregano extract / $0.075 \%$ basil extract; F5: $0.1 \%$ oregano extract / $0.1 \%$ basil extract; F6: Control; F7: 0.01\% BHT.

a-d Same lowercase letters in the column indicate that there is no difference between the formulations (Tukey, $p>0.05$ ). A-C Same capital letters in the column indicate that there is no difference between the days evaluated for the same formulation (Tukey, $p>0.05$ ). 
Texture is an important physical property that directly influences sensory characteristics. Texture profile analysis (Table $7)$ revealed reductions ( $p<0.05)$ in hardness and chewiness of samples between days 5 and 54 of storage. Adhesiveness, however, did not differ $(p>0.05)$ throughout the evaluation period for F6.

Springiness differed among formulations, but resilience did not vary during storage $(p<0.05)$. However, hardness, essential for meat products (Soncu et al., 2015), decreased markedly, possibly due to lower dehydration of products during storage. Bozkurt and Bayram (2006) reported increases $(p<0.05)$ in hardness and chewiness, but reductions $(p<0.05)$ in adhesiveness, springiness, and cohesiveness, besides a lack of change in resilience $(p>0.05)$ in sausages during a 15-day curing period.

Table 7

Texture profile (TPA) of linguiças calabresas (traditional Brazilian sausage) formulated with the addition of oregano and basil extracts at 05 and 54 days of storage

\begin{tabular}{|c|c|c|c|c|c|c|}
\hline \multirow[b]{2}{*}{ Formulations } & \multicolumn{6}{|c|}{ Parameters (05 days) } \\
\hline & $\begin{array}{l}\text { Hardness } \\
\text { (N) }\end{array}$ & $\begin{array}{l}\text { Adhesiveness } \\
\text { (N.s) }\end{array}$ & Springiness & Cohesiveness & $\begin{array}{l}\text { Chewness } \\
\text { (N) }\end{array}$ & Resilience \\
\hline F1 & $21998^{\mathrm{aA}} \pm 4060$ & $45^{\mathrm{aA}} \pm 15$ & $0.92^{\mathrm{aB}} \pm 0.04$ & $0.77^{\mathrm{abA}} \pm 0.03$ & $16751^{\mathrm{aA}} \pm 2060$ & $0.39^{\mathrm{aA}} \pm 0.03$ \\
\hline $\mathrm{F} 2$ & $17884^{\mathrm{aA}} \pm 2095$ & $39^{\mathrm{aA}} \pm 9.0$ & $0.94^{\mathrm{aA}} \pm 0.05$ & $0.74^{\mathrm{abB}} \pm 0.03$ & $12909^{\mathrm{bA}} \pm 1391$ & $0.36^{\mathrm{aA}} \pm 0.03$ \\
\hline F3 & $22956^{\mathrm{aA}} \pm 3876$ & $58^{\mathrm{aA}} \pm 12$ & $0.91^{\mathrm{aA}} \pm 0.04$ & $0.77^{\mathrm{abA}} \pm 0.04$ & $16771^{\mathrm{aA}} \pm 1824$ & $0.40^{\mathrm{aA}} \pm 0.02$ \\
\hline F4 & $19669^{\mathrm{aA}} \pm 2234$ & $61^{\mathrm{aA}} \pm 6.9$ & $0.92^{\mathrm{aA}} \pm 0.02$ & $0.77^{\mathrm{aA}} \pm 0.02$ & $13071^{\mathrm{bA}} \pm 843$ & $0.38^{\mathrm{aA}} \pm 0.03$ \\
\hline F5 & $16735^{\mathrm{aA}} \pm 1124$ & $59^{\mathrm{aA}} \pm 13$ & $0.91^{\mathrm{aA}} \pm 0.04$ & $0.73^{\mathrm{bA}} \pm 0.04$ & $11609^{\mathrm{bA}} \pm 902$ & $0.34^{\mathrm{aA}} \pm 0.03$ \\
\hline F6 & $15139^{\mathrm{aA}} \pm 2067$ & $42^{\mathrm{aA}} \pm 22$ & $0.92^{\mathrm{aA}} \pm 0.05$ & $0.76^{\mathrm{abA}} \pm 0.04$ & $12045^{\mathrm{bA}} \pm 1783$ & $0.37^{\mathrm{aA}} \pm 0.03$ \\
\hline F7 & $21364^{\mathrm{aA}} \pm 3021$ & $55^{\mathrm{aA}} \pm 9.8$ & $0.90^{\mathrm{aA}} \pm 0.07$ & $0.79^{\mathrm{aA}} \pm 0.02$ & $13991^{\mathrm{abA}} \pm 1922$ & $0.40^{\mathrm{aA}} \pm 0.02$ \\
\hline \multicolumn{7}{|c|}{ Parameters (54 days) } \\
\hline Formulations & $\begin{array}{l}\text { Hardness } \\
\text { (N) }\end{array}$ & $\begin{array}{l}\text { Adhesiveness } \\
\text { (N.s) }\end{array}$ & Springiness & Cohesiveness & $\begin{array}{l}\text { Chewness } \\
\text { (N) }\end{array}$ & Resilience \\
\hline F1 & $10157^{\mathrm{abB}} \pm 1951$ & $4.1^{\mathrm{aB}} \pm 3.0$ & $0.97^{\mathrm{aA}} \pm 0.05$ & $0.79^{\mathrm{aA}} \pm 0.05$ & $7825^{\mathrm{aB}} \pm 839$ & $0.41^{\mathrm{aA}} \pm 0.04$ \\
\hline $\mathrm{F} 2$ & $10170^{\mathrm{abB}} \pm 1460$ & $7.1^{\mathrm{abB}} \pm 2.8$ & $0.93^{\mathrm{abA}} \pm 0.04$ & $0.77^{\mathrm{aA}} \pm 0.03$ & $7272^{\mathrm{aB}} \pm 777$ & $0.37^{\mathrm{abA}} \pm 0.02$ \\
\hline F3 & $9742^{\mathrm{abB}} \pm 1783$ & $15^{\mathrm{abB}} \pm 8.8$ & $0.90^{\mathrm{bA}} \pm 0.06$ & $0.76^{\mathrm{aA}} \pm 0.05$ & $6845^{\mathrm{abB}} \pm 1147$ & $0.38^{\mathrm{abA}} \pm 0.03$ \\
\hline F4 & $7288^{\mathrm{bB}} \pm 979$ & $16^{\mathrm{abB}} \pm 7.0$ & $0.92^{\mathrm{bA}} \pm 0.02$ & $0.78^{\mathrm{aA}} \pm 0.02$ & $5600^{\mathrm{bB}} \pm 401$ & $0.37^{\mathrm{abA}} \pm 0.02$ \\
\hline F5 & $10310^{\mathrm{aB}} \pm 1359$ & $10^{\mathrm{abB}} \pm 3.2$ & $0.88^{\mathrm{bB}} \pm 0.04$ & $0.75^{\mathrm{aA}} \pm 0.04$ & $6702^{\mathrm{abB}} \pm 568$ & $0.35^{\mathrm{abA}} \pm 0.03$ \\
\hline F6 & $9465^{\mathrm{abB}} \pm 2175$ & $11^{\mathrm{abA}} \pm 4.2$ & $0.94^{\mathrm{abA}} \pm 0.03$ & $0.78^{\mathrm{aA}} \pm 0.04$ & $7437^{\mathrm{aB}} \pm 787$ & $0.36^{\mathrm{abA}} \pm 0.03$ \\
\hline F7 & $8172^{\mathrm{abB}} \pm 1666$ & $21^{\mathrm{bB}} \pm 13$ & $0.92^{\mathrm{abA}} \pm 0.05$ & $0.76^{\mathrm{aA}} \pm 0.07$ & $6425^{\mathrm{abB}} \pm 822$ & $0.33^{\mathrm{bA}} \pm 0.05$ \\
\hline
\end{tabular}

F1: $0.05 \%$ oregano extract / $0.05 \%$ basil extract; F2: $0.1 \%$ oregano extract / $0.05 \%$ basil extract; F3: $0.05 \%$ oregano extract / $0.1 \%$ basil extract; F4: $0.075 \%$ oregano extract / $0.075 \%$ basil extract; F5: $0.1 \%$ oregano extract / $0.1 \%$ basil extract; F6: Control; F7: 0.01\% BHT.

a-b Same lowercase letters in the column indicate that there is no difference between the formulations (Tukey, $p>0.05$ ).

А-B Same capital letters in the column indicate that there is no difference between the days evaluated for the same formulation (Tukey, $p>0.05$ ). 
Hardness, adhesiveness, springiness, and resilience did not differ $(p>0.05)$ among formulations at 5 days of storage. At 54 days, no differences $(p>0.05)$ in cohesiveness were observed. Nevertheless, texture changes could not be correlated with extract addition to formulations.

\section{Conclusions}

Oregano and basil extracts showed antioxidant activity, thus having the potential to be used in the food industry. The addition of oregano and basil extracts to linguiça calabresa formulations did not significantly alter their quality parameters. Simultaneous addition of oregano and basil extracts in different proportions (from 0.05 to $0.1 \%$ ) was as efficient as BHT addition.

\section{Acknowledgments}

The authors thank the State University of Londrina (UEL), the Brazilian Federal Agency for Support and Evaluation of Graduate Education (CAPES), the Graduate Program in Food Sciences at UEL, and the Federal University of Technology of Paraná (Francisco Beltrão campus) for their support.

\section{References}

Agência Nacional de Vigilância Sanitária (2005). Resolução de Diretoria Colegiada - RDC no 727, de 22 de setembro de 2005. Regulamento técnico para produtos de vegetais, produtos de frutas e cogumelos comestíveis. Diário Oficial da União, Brasília, DF, Brasil. Recuperado de http://antigo.anvisa.gov.
br/documents/10181/2718376/RDC_ 272_2005_.pdf/40ddbf30-4939-403ea9d1-fbab47ffc5bb

Alezandro, M. R., Lui, M. C. Y., Lajolo, F. M., \& Genovese, M. I. (2011). Commercial spices and industrial ingredients: evaluation of antioxidant capacity and flavonoids content for functional foods development. Ciência e Tecnologia de Alimentos, 31(2), 527-533. doi: 10.1590/ S0101-20612011000200038

Alves, L. A. A. S., Lorenzo, J. M., Gonçalves, C. A. A., Santos, B. A., Heck, R. T., Cichoski, A. J., \& Campagnol, P. C. B. (2016). Production of healthier bologna type sausages using pork skin and green banana flour as a fat replacers. Meat Science, 121, 73-78. doi: 10.1016/j.meatsci.2016.06.001

Association of Official Analytical Chemists (1995). Official methods of analysis of the AOAC international. Arlington: AOAC.

Barbosa, T. C. M., Clemente, J. N., Chaves, K. S., Fonseca, S. B., \& Meireles, B. R. L. A. (2019). Linguiça frescal bovina adicionada de extratos de alecrim (Rosmarinus officinalis) e chá verde (Carmellia sinensis): Parâmetros físico-químicos e estabilidade oxidativa. Revista Científica de Produção Animal, 21(1), 5-12. doi: 10.5935/2176-4158/rcpa.v21n1p5-12

Benzie, I. F. F., \& Strain, J. J. (1996). The ferric reducing ability of plasma (FRAP) as a measure of "antioxidant power": the FRAP assay. Analytical Biochemistry, 239(292), 70-76. doi: 10.1006/abio.1996.0292

Bhale, S. D., Xu, Z., Prinyawiwatkul, W., King, J. M., \& Godber, J. S. (2007). Oregano and rosemary extracts inhibit oxidation of long-chain n-3 fatty acids in menhaden oil. 
Journal of Food Science, 72(9), 504-508. doi: 10.1111/j.1750-3841.2007.00569.x

Boeira, C. P., Piovesan, N., Flores, D. C. B., Soquetta, M. B., Lucas, B. N., Heck, R. T.,... Terra, N. N. (2020). Phytochemical characterization and antimicrobial activity of Cymbopogon citratus extract for application as natural antioxidant in fresh sausage. Food Chemistry, 319, 126553. doi: 10.1016/j.foodchem.2020.126553

Bourne, M. C. (1978). Texture profile analysis. Food Technology, 32(7), 62-72.

Bozkurt, H., \& Bayram, M. (2006). Colour and textural attributes of sucuk during ripening. Meat Science, 73(2), 344-350. doi: 10.1016/j.meatsci.2006.01.001

Brand-Williams, W., Cuvelier, M. E., \& Berset, C. (1995). Use of a free radical method to evaluate antioxidant activity. Food Science and Technology, 28(1), 25-30. doi: 10.1016/S0023-6438(95)80008-5

Brewer, M. S. (2011). Natural antioxidants: sources, compounds, mechanisms of action, and potential applications. Comprehensive Reviews in Food Science and Food Safety, 10(4), 221-247. doi: 10.1111/j.1541-4337.2011.00156.x

Carbonera, N., \& Espírito Santo, M. L. P. (2010). Atividade do Lactobacillus plantarum na preservação da anchoita (Engraulis anchoita) fermentada. Revista Instituto Adolfo Lutz, 69(2), 201-207.

Castellucci, C. M. N. (2004). Influência do método de cocção no valor nutritivo, qualidade lipídica e formação de óxidos de colesterol em linguiças calabresas à vácuo e granel. Dissertação de mestrado, Faculdade de Ciências Farmacêuticas da Universidade de São Paulo, São Paulo, SP,
Brasil. Recuperado de https://www.teses. usp.br/teses/disponiveis/89/89131/tde04052015-181117/publico

Channon, H. A., \& Trout, G. R. (2002). Effect of tocopherol concentration on rancidity development during frozen storage of a cured and an uncured processed pork product. Meat Science, 62(1), 9-17. doi: 10.1016/S0309-1740(01)00221-2

De Carli, E. M., Terra, N. N., Fries, L. L. M., Menezes, C. R., \& Palezi, S. C. (2013). Descontaminação de cortes suínos com ácidos orgânicos comerciais, solução salina acidificada e luz ultravioleta. Semina: Ciências Agrárias, 34(3), 11951204. doi: $10.5433 / 1679-0359.2013 v 34$ n3p1195

Del Ré, P. V., \& Jorge, N. (2012). Especiarias como antioxidantes naturais: aplicações em alimentos e implicação na saúde. Revista Brasileira de Plantas Medicinais, 14(2), 389-399. doi: 10.1590/S1516-057 22012000200021

Faion, A. M., Beal, P., Ril, F. T., Cichoski, A. J., Cansian, R. L., Valduga, A. T.,... Valduga, E. (2015). Influence of the addition of natural antioxidant from mate leaves (Ilex paraguariensis St. Hill) on the chemical, microbiological and sensory characteristics of different formulations of Prato cheese. Journal of Food Science and Technology, 52(3), 1516-1524. doi: 10.1007/s13197-013-1045-4

Fernandes, R. P. P., Trindade, M. A., Lorenzo, J. M., Munekata, P. E. S., \& Melo, M. P. (2016b). Effects of oregano extract on oxidative, microbiological and sensory stability of sheep burgers packet in modified atmosphere. Food Control, 63, 65-75. doi: 10.1016/j.foodcont.2015.11.027 
Fernandes, R. P. P., Trindade, M. A., Tonin, F. G., Lima, C. G., Pugine, S. M. P., Munekata, P. E. S.,... Melo, M. P. (2016a). Evaluation of antioxidant capacity of 13 plant extracts by three different methods: cluster analyses applied for selection of the natural extracts with higher antioxidant capacity to replace synthetic antioxidant in lamb burgers. Journal of Food Science and Technology, 53(1), 451-460. doi: 10. 1007/s13197-015-1994-X

Fukayama, E. H., Bertechini, A. G., Geraldo, A., Kato, R. K., \& Murgas, L. D. S. (2005). Extrato de orégano como aditivo em rações para frangos de corte. Revista Brasileira de Zootecnia, 34(6), 2316-2326. doi: 10.1590/S1516-35982005000700018

Gandra, E. A., Nogueira, M. B., Chim, J. F., Machado, M. R. G., Rodrigues, R. S., Zambiazi, R. C.,... Freitas, P. F. (2013). Potencial antimicrobiano e antioxidante de extratos vegetais de alecrim, erva doce, estragão e orégano. Revista de Ciencia y Tecnologia, 15(20), 24-29.

Gonçalves, J. H. T., Santos, A. S., \& Morais, H. A. (2015). Atividade antioxidante, compostos fenólicos totais e triagem fitoquímica de ervas condimentares desidratadas. Revista da Universidade Vale do Rio Verde, 13(1), 486-497. doi: 10.5892/ruvrd. v13i1.2003

Instituto Adolfo Lutz (2008). Métodos físicoquímicos para análise de alimentos (4a ed.). São Paulo: IAL.

Joseph, S., Chatli, M. K., Biswas, A. K., \& Sahoo, J. (2014). Oxidative stability of pork emulsion containing tomato products and pink guava pulp during refrigerated aerobic storage. Journal of Food Science and Technology, 51(11), 3208-3216. doi: 10.1007/s13197-012-0820-y
Karabagias, I., Badeka, A., \& Kontominas, M. G. (2011). Shelf life extension of lamb meat using thyme or oregano essential oils and modified atmosphere packaging. Meat Science, 88(1), 109-116. doi: 10.1016/ j.meatsci.2010.12.010

Karre, L., Lopez, K., \& Getty, K. L. K. (2013). Natural antioxidants in meat and poultry products. Meat Science, 94(2), 220-227. doi: 10.1016/j.meatsci.2013.01.007

Kim, S., Cho, A. R., \& Han, J. (2013). Antioxidant and antimicrobial activities of leafy green vegetable extracts and their applications to meat product preservation. Food Control, 29(1), 112-120. doi: 10.1016/j. foodcont.2012.05.060

Krishnan, K. R., Babuskin, S., Babu, P. A. S., Sasikala, M., Sabina, K., Archana, G.,... Sukumar, M. (2014). Antimicrobial and antioxidant effects of spice extracts on the shelf life extension of raw chicken meat. International Journal of Food Microbiology, 171, 32-40. doi: 10.1016/j. ijfoodmicro.2013.11.011

Kumazawa, S., Hamasaka, T., \& Nakayama, T. (2004). Antioxidant activity of propolis of various geographic origins. Food Chemistry, 84(3), 329-339. doi: 10.1016/ S0308-8146(03)00216-4

Leão, L. L., Oliveira, F. S., Souza, R. S., Farias, P. K. S., Fonseca, F. S. A., Martins, E. R., \& Souza, R. M. (2017). Uso de antioxidantes naturais em carnes e seus subprodutos. Caderno de Ciências Agrárias, 9(1), 94100.

Leygonie, C., Britz, T. J., \& Hoffman, L. C. (2012). Impact of freezing and thawing on the quality of meat: Review. Meat Science, 91(2), 93-98. doi: 10.1016/j. meatsci.2012.01.013 
Lima, D. M., Jr., Rangel, A. H. N., Urbano, S. A., \& Moreno, G. M. B. (2013). Oxidação lipídica e qualidade da carne ovina. Acta Veterinaria Brasilica, 7(1), 14-28. doi: 10. 21708/avb.2013.7.1.3119

Lorenzo, J. M., González-Rodríguez, R. M., Sánchez, M.,Amado, I.R.,\&Franco, D. (2013). Effects of natural (grape seed and chestnut extract) and synthetic antioxidants (buthylatedhydroxytoluene, BHT) on the physical, chemical, microbiological and sensory characteristics of dry cured sausage "chorizo". Food Research International, 54(1), 611-620. doi: 10.10 16/j.foodres.2013.07.064

Lorenzo, J. M., Temperán, S., Bermúdez, R., Cobas, N., \& Purriños, L. (2012). Changes in physico-chemical, microbiological, textural and sensory attributes during ripening of dry-cured foal salchichón. Meat Science, 90(1), 194-198. doi: 10. 1016/j.meatsci.2011.06.025

Mantovani, D., Corazza, M. L., Cardozo, L., Fº., \& Costa, S. C. (2011). Avaliação higiênicosanitária de linguiças tipo frescal após inspeção sanitária realizada por órgãos federal, estadual e municipal na região noroeste do Paraná. Revista Saúde e Pesquisa, 4(3), 357-362.

Marangoni, C., \& Moura, N. F. (2011). Antioxidant activity of essential oil from Coriandrum sativum L. in Italian salami. Ciência e Tecnologia de Alimentos, 31(1), 124128. doi: 10.1590/S0101-206120110001 00017

Mariutti, L. R. B., \& Bragagnolo, N. (2007). Revisão: antioxidantes naturais da Família Lamiaceae. Aplicação em produtos alimentícios. Brazilian Journal of Food Technology, 10(2), 96-103.
Mariutti, L. R. B., Barreto, G. P. M., Bragagnolo, N., \& Mercadante, A. Z. (2008). Free radical scavenging activity of ethanolic extracts from herbs and spices commercialized in Brazil. Brazilian Archives of Biology and Technology, 51(6), 1225-1232. doi: 10.1590/S1516-89132008000600018

Mendes, G. M., Rodrigues-das-Dores, R. G., \& Campideli, L. C. (2015). Avaliação do teor de antioxidantes, flavonoides e compostos fenólicos em preparações condimentares. Revista Brasileira de Plantas Medicinais, 17(2), 297-304. doi: 10.1590/1983-084X/13_069

Ministério da Agricultura, Pecuária e Abastecimento (2000). Instrução Normativa $\mathrm{n}^{\circ} 4$ de 31 de março de 2000. Anexo III. Regulamento técnico de Identidade e Qualidade de Linguiça. Diário Oficial da União, Brasília, DF, Brasil. Recuperado de http:// extranet.agricultura.gov.br/sislegisconsulta/consultarLegislacao.do? operacao=visualizar\&id=7778

Oliveira, R. R., Lage, M. E., Silveira, O. J., Neto, \& Sales, M. C. (2012). Antioxidantes naturais em produtos cárneos. PUBVET, 6(10), 1319-1324.

Paschoal, E. C., Beltrami, J. M., Santos, I. C., Germano, R. M., Soares, A. A., Dias, J. C. P.,... Otutumi, L. K. (2019). Estabilidade oxidativa da carne e derivados cárneos com o uso de antioxidantes naturais ou sintéticos publicados na base de dados da Scielo: revisão de literatura. Medicina Veterinária, 13(1), 136-142. doi: 10.26605/ medvet-v13n1-2621

Pitaro, S. P., Fiorani, L. V., \& Jorge, N. (2012). Potencial antioxidante dos extratos de manjericão (Ocimum basilicum 
Lamiaceae) e orégano (Origanum vulgare Lamiaceae) em óleo de soja. Revista Brasileira de Plantas Medicinais, 14(4), 686-691. doi: 10.1590/S1516-057220 12000400017

Ribeiro, J. S., Santos, M. J. M. C., Silva, L. K. R., Pereira, L. C. L., Santos, I. A., Lannes, S. C. S., \& Silva, M. V. (2019). Natural antioxidants used in meat products: A brief review. Meat Science, 148, 181-188. doi: 10.1016/j.meatsci.2018.10.016

Rufino, M. S. M., Alves, R. E., Brito, E. S., Morais, S. M., Sampaio, C. G., Pérez-Jiménez, J., \& Saura-Calixto, F. D. (2007a). Metodologia científica: determinação da atividade antioxidante total em frutas pela captura do radical livre $D P P H$. (Comunicado Técnico online 127). Fortaleza: Empresa Brasileira de Pesquisa Agropecuária.

Rufino, M. S. M., Alves, R. E., Brito, E. S., Morais, S. M., Sampaio, C. G., Pérez-Jiménez, J., \& Saura-Calixto, F. D. (2007b). Metodologia científica: determinação da atividade antioxidante total em frutas pela captura do radical livre $A_{B T S}{ }^{+}$. (Comunicado Técnico online 128). Fortaleza: Empresa Brasileira de Pesquisa Agropecuária.

Sánchez-González, I., Jiménez-Escrig, A., \& Saura-Calixto, F. (2005). In vitro antioxidant activity of coffees brewed using different procedures (Italian, espresso and filter). Food Chemistry, 90(1-2), 133-139. doi: 10.1016/j.foodchem.2004.03.037

Schwert, R. (2009). Uso de fumaça líquida em linguiça tipo calabresa cozida e defumada. Dissertação de mestrado, Universidade Regional Integrada do Alto Uruguai e das Missões, Erechim, RS, Brasil. Recuperado de https://www.uricer.edu.br/cursos/arq trabalhos_usuario/2189.pdf
Schwert, R., Verlindo, R., Cichoski, A. J., Oliveira, D., \& Valduga, E. (2011). Comparative evaluation of liquid and traditional smoke on oxidative stability, color and sensory properties of Brazilian calabrese sausage. CyTA - Journal of Food, 9(2), 131-134. doi: 10.1080/19476337.2010.491581

Shah, M. A., Bosco, S. J. D., \& Mir, S. A. (2014). Plant extracts as natural antioxidants in meat and meat products. Meat Science, 98(1), 21-23. doi: 10.1016/j.meatsci.20 14.03 .020

Soncu, E. D., Kolsarici, N., Çiçek, N., Öztürk, G. S., Akoglu, I. T., \& Arici, Y. K. (2015). The comparative effect of carrot and lemon fiber as a fat replacer on physicochemical, textural, and organoleptic quality of low-fat beef hamburger. Korean Journal for Food Science of Animal Resources, 35(3), 370-381. doi: 10.5851/ kosfa.2015.35.3.370

Sousa, C. M. M., Silva, H. R., Vieira, G. M., Jr., Ayres, M. C. C., Costa, C. L. S., Araújo, D. S.,... Chaves, M. H. (2007). Fenóis totais e atividade antioxidante de cinco plantas medicinais. Química Nova, 30(2), 351-355. doi: 10.1590/S0100-40 422007000200021

Statsoft (2005). Statistica. Release 7. Copyright.

Taghvaei, M., \& Jafari, S. M. (2015). Application and stability of natural antioxidants in edible oils in order to substitute synthetic additives. Journal of Food Science and Technology, 52(3), 1272-1282. doi: 10.10 07/s13197-013-1080-1

Tarladgis, B. G., Pearson, A. M., \& Dugan Jun, L. R. (1964). Chemistry of the 2- thiobarbituric acid test for determination of oxidative 
rancidity in foods - II Formation of the TBA - Malonaldehyde complex without acidheat treatment. Journal of the Science and Food Agriculture, 15(9), 602-607. doi: 10.1002/jsfa.2740150904

Utrera, M., \& Estévez, M. (2013). Oxidative damage to poultry, pork, and beef during frozen storage through the analysis of novel protein oxidation markers. Journal of Agricultural and Food Chemistry, 61(33), 7987-7993. doi: 10.1021/jf402220q

Zago, G. R. (2018). Estabilidade oxidativa de linguiça tipo Toscana com extrato liofilizado de casca de romã (Punica granatum L.). Dissertação de mestrado, Universidade de Passo Fundo, Passo Fundo, RS, Brasil. Recuperado de http:// tede.upf.br/jspui/handle/tede/1378
Zago, G. R., Gottardo, F. M., Bilibio, D., Freitas, C. P., Bertol, C. D., Dickel, E. L., \& Santos, L. R. (2020). Pomegranate (Punica granatum L.) peel lyophilized extract delays as lipid oxidation in tuscan sausages. Ciência Rural, 50(4), 1-10. doi: 10.1590/0103-84 $78 \mathrm{cr} 20190689$

Zehiroglu, C., \& Sarikaya, S. B. O. (2019). The importance of antioxidants and place in today's scientific and technological studies. Journal of Food Science and Technology, 56(11), 4757-4774. doi: 10. 1007/s13197-019-03952-x

Zhang, W., Xiao, S., Samaraweera, H., Lee, E. J., \& Ahn, D. U. (2010). Improving functional value of meat products. Meat Science, 86(1), 15-31. doi: 10.1016/j. meatsci.2010.04.018 